\title{
Values and materialism as predictors of pro-environmental attitudes
}

\author{
P. Uram ${ }^{1}$, S. Skalski ${ }^{1}$, A. Kwiatkowska ${ }^{1}$ \\ 1 Institute of Psychology, Polish Academy of Sciences, Warsaw, Poland \\ 1 Stefana Jaracza Str., 00-378 Warsaw, Poland
}

Authors:
Patrycja Uram
e-mail: patrycja.uram@sd.psych.pan.pl
ORCID: 0000-0002-9927-2916
Sebastian Skalski
e-mail: sebastian.skalski@sd.psych.pan.pl
ORCID: 0000-0002-6336-7251
Anna Kwiatkowska
e-mail: akwiatkowska@psych.pan.pl
ORCID: 0000-0002-5867-7079
Copyright:
C) The Authors (2021).
Published by Herzen State Pedagogical
University of Russia.

\begin{abstract}
There is still no consensus regarding what values and what dimensions of materialism are significant predictors of pro-environmental attitudes. Based on Schwartz's theory of values, the literature states the values that positively affect pro-environmental behaviours are: self-transcendence, openness to change, and universalism. On the other hand, self-enhancement value has a negative impact. Thus, the aim of this paper was to expand the knowledge available on the subject. To this end, the following study tools were used: NEP (New Ecological Paradigm), PVQ-40 (Portrait Value Questionnaire-40) and MVS (Material Values Scale). Study's participants counted $\mathrm{N}=476$ individuals aged 18-30 $(M=21,53 ; S D=2,94), 35 \%$ were women. Results have shown the strongest positive correlation between the value of power and materialism and a negative correlation between materialism and pro-environmental attitudes. Moreover, analyses conducted using the Student's
\end{abstract} t-test for independent samples have shown that women presented a higher level of pro-environmental attitudes, including human power and limits of nature. A regression analysis has shown that both success and centrality (materialism) have been significant predictors of pro-environmental attitudes, as well as universalism, tradition and hedonism (values). These results have practical value and may be used to shape changes in attitudes and habits relevant to climate changes.

Keywords: environment, materialism, values, pro-environmental attitude. 
УдК 159.9

\title{
Ценности и материализм как предикторы проэкологических установок
}

\author{
П. Урам ${ }^{1}$, С. Скальски ${ }^{1}$, А. Квятковска ${ }^{1}$ \\ ${ }^{1}$ Институт психологии Польской академии наук \\ 00-378, Польша, Варшава, ул. Стефана Ярача, д. 1
}

\author{
Сведения об авторах: \\ Патрисия Урам \\ e-mail: patrycja.uram@sd.psych.pan.pl \\ ORCID: 0000-0002-9927-2916 \\ Себастьян Скальски \\ e-mail: sebastian.skalski@sd.psych.pan.pl \\ ORCID: 0000-0002-6336-7251
}

\section{Анна Квятковска \\ e-mail: akwiatkowska@psych.pan.pl \\ ORCID: 0000-0002-5867-7079 \\ (C) Авторы (2021). \\ Опубликовано Российским \\ государственным педагогическим \\ университетом им. А. И. Герцена.}

Аннотация. До сих пор нет единого мнения относительно того, какие ценности и какие аспекты материализма являются значимыми предикторами отношения к окружающей среде. В исследованиях, построенных с опорой на теорию ценностей Шварца, установлено, что ценностями, которые положительно влияют на проэкологическое поведение, являются самопревосхождение, открытость к изменениям и универсализм. В свою очередь, ценность самосовершенствования оказывает негативное влияние. Цель данной статьи состояла в том, чтобы расширить имеющиеся знания по данному вопросу. Использоввались следующие инструменты исследования: NEP (Новая экологическая парадигма), PVQ-40 (Опросник портретных ценностей-40) и MVS (Шкала материальных ценностей). Участниками исследования стали 476 человек в возрасте 18-30 лет $(\mathrm{M}=21,53 ; \mathrm{SD}=2,94), 35$ \% женщин. Результаты показали самую сильную положительную корреляцию между ценностью власти и материализмом и отрицательную корреляцию между материализмом и отношением к окружающей среде. Кроме того, анализ, проведенный с использованием t-критерия Стьюдента для независимых выборок, показал, что женщины демонстрировали более высокий уровень отношения к окружающей среде, включая силу человека и пределы природы. Регрессионный анализ показал, что как успех, так и центральное положение (материализм) являются значимыми предикторами проэкологических установок, а также универсализма, традиций и гедонизма (ценностей). Эти результаты имеют практическую ценность и могут быть использованы для формирования изменений в установках и привычках, связанных с изменением климата.

Ключевые слова: окружающая среда, материализм, ценности, проэкологическое отношение. 


\section{Introduction}

It is believed that along with the emergence and deepening of the ecological crisis there came about a necessity of changing the way people think and how they treat the environment (Cordano, Welcomer, Scherer 2003). The tool used most often to diagnose attitudes and environmental behaviours is the New Ecological Paradigm (NEP) created by Dunlap et al. (Dunlap, Van Liere, Mertig et al. 2000). Conceptualisation is based on the high value assigned to the environment, compassion to other species, avoiding environmental threats and respecting nature. The key aspect of the so-called pro-environmental orientation is cooperation and open participation of societies in planning long-term solutions for the environment (Erdogan 2009). NEP presents a concept of the human-nature relation in which neither side dominates the other. Together with the conceptualisation, a NEP scale has been developed to measure attitudes towards the environment (Lundmark 2007). We can, therefore, study how people perceive the environment and what they think and feel about it, as NEP is a measure of cognitive aspects of pro-environmental attitudes (Dyr, Prusik 2020). In the face of progressing degradation of the environment, it seems crucial to determine the predictors of the pro-environmental orientation.

There are many concepts of materialism. It may be understood as the realisation of external life goals (Kasser, Ryan 1993); it may refer to the importance of possessing material goods, and thus be linked with such personality variables as envy or unwillingness to share (Belk 1985). Furthermore, materialism may be correlated with reinforcement of one's identity and the Self through experiencing consumerism understood not only as purchasing material goods, but also everything that accompanies that (Shrum, Wong, Arif et al. 2013). Then, according to the definition proposed by Marsh Richins and Scott Dawson (1992), materialism is a specific characteristic of an individual who partakes in the consumerism culture. Materialism is, then, perceived as the value that determines people's actions and situational behaviours. Conceptualisation of materialism made by Richins and Dawson (1992) assumes three aspects of this phenomenon: centrality of amassing material goods in an individual's life, amassing goods as the determinant of happiness, and defining life success as owning a specific amount of material goods of specific quality. According to this approach, materialists are individuals to whom the major goal in life, and their main activity, is collecting material goods.

The topic of materialism has been a subject of numerous studies for many years (Dittmar, Bond, Hurst et al. 2014). For instance, results obtained in a study by Liu et al. show that people who are more concerned with materialistic values are less interested in caring for and saving the environment. Similar conclusions have been drawn from studies by Anderson and Nässén (2016), and Gatersleben et al. (Gatersleben, Jackson, Meadows et al. 2018), whereby the materialistic values were negatively correlated with the level of concern for the environment. Study by Gu et al. (Gu, Gao, Wang et al. 2018) has shown that materialism was negatively correlated with pro-environmental attitudes. Hurst and associates (Hurst, Dittmar, Bond et al. 2013) have concluded that materialistic individuals believed less often that the world is endangered and that they should accept responsibility for protecting the environment. Kilbourne and Pickett (2008) have stated that materialism will have a negative effect on environmental beliefs. Furthermore, materialism was a mediator in the relationship between Schwartz's values and the frequency of shopping (consumerism) (Sevgili, Cesur 2014).

Previous studies based on Schwartz's theory of values have shown that values that have a positive effect on environmental behaviours are: self-transcendence, openness to change and universalism. The value that has a negative effect, on the other hand, is self-reinforcement (Karp 1996). Previous studies state that values (seen as emotions-related cognitive representations of desired goals) and materialism may affect strengthening of the pro-environmental attitudes (Karp 1996; Liobikienè, Liobikas, Brizga et al. 2020; Plombon 2011). 
Although the interest of scholars in psychological aspects of ecological issues is growing, in Poland, studies on pro-environmental attitudes have been few (e. g., Byrka 2015; Dyr, Prusik 2020). Thus, we decided to conduct research on a Polish sample of young people to examine possible predictors of their attitudes toward environment. Therefore, the aim of the study is to identify values that may be significant predictors of pro-environmental attitudes, and to examine the role of materialism and its three facets in the prediction of those attitudes. Also, we would like to look into differences between men and women regarding pro-environmental attitudes, since researchers claim that women typically demonstrate greater environmental concern and involvement in environmentally significant behaviours, as compared to men (e.g., Zelezny, Chua, Aldrich 2000). However, Hunter, Hatch and Johnson (2004) explored gender differences in private and public environmentally-oriented behaviours across 22 nations and concluded that while some gender differences were revealed, these differences were inconsistent across the studied nations.

\section{Materials and methods}

A total of $\mathrm{N}=467$ individuals aged 18 to 30 years $(M=21.53 ; S D=2.94)$ participated in the study, of which $35 \%$ were female.

The study was conducted between May and June 2021. Participation was anonymous and voluntary, overseen with the use of the Prolific platform. Participation in the project was remunerated with a payment of 10 zlotych to each participant (equivalent of about 2 euros). The study procedure was positively evaluated by the Ethics Committee of the Institute of Psychology of the Polish Academy of Sciences. Prior to completing the online questionnaires, each participant familiarised themselves with the purpose of the study, its procedure, and gave their informed consent to participate. The procedure involved completing four questionnaires: the NEP (New Ecological Paradigm) for measuring pro-environmental orientation, the PVQ-40 (Portrait Value Questionnaire-40) for measuring values according to Schwartz's theory, the MVS (Material Values Scale) to measure materialism and a sociodemographic questionnaire prepared for the purpose of this study.

We used the following diagnostic tools:

1. The questionnaire collecting the demographic information, such as age, gender, level of education, place of residence, marital status, professional status and financial situation.

2. The New Ecological Paradigm (NEP) scale developed by Dunlap et al., (Dunlap, Van Liere, Mertig et al. 2000), and adapted into Polish by Dyr and Prusik (2020), was used to assess pro-environmental attitudes and behaviours. The NEP contains 15 statements respondents assess using a fivepoint Likert scale, where 5 represents "I definitely agree" and 1 represents "I definitely do not agree." The NEP consists of two subscales: Human Power, e.g., Humans were meant to rule over the rest of nature $(\alpha=.76)$, and Limits of Nature, e.g., Earth is like a spaceship, with limited room and resources $(\alpha=.62)$. The whole scale has a satisfactory level of reliability $(\alpha=.81)$. We computed three indices: based on 15 items (NEP-Pro-Environmental Attitude), based on the Human Power subscale (NEPPower), and based on the Limits of Nature subscale (NEP-Limits). We obeyed the following rule: "higher scores represent higher pro-environmental attitudes", so in the case of the Human Power subscale, we reversed relevant items.

3. The Portrait Value Questionnaire-40 (PVQ-40) developed by Schwartz et al., (2001), and adapted into Polish by Cieciuch \& Zaleski (2011), was used to measure preference for values. PVQ-40 is a basic questionnaire measuring 10 types of values in the classic model proposed by Schwartz: Conformity $(\alpha=.59)$, Tradition $(\alpha=.60)$, Benevolence ( $\alpha=.63)$, Universalism ( $\alpha=.78)$, Self-Direction ( $\alpha=.66)$, Stimulation $(\alpha=.70)$, Hedonism $(\alpha=.83)$, Achievement ( $\alpha=.75)$, Power $(\alpha=.61)$, Security $(\alpha=.57)$. The scale is made up of 40 items, which respondents assess using 
a six-point scale, where 1 represents "Not like me at all" and 6 represents "Very much like me."

4. The Material Values Scale (MVS) developed by Richins and Dawson (1992), and adapted into Polish Górnik-Durose (2016), was used to measure materialism. The scale is made up of 15 items which respondents assess using a five-point scale, where 1 represents "I definitely do not agree" and 5 represents "I definitely agree. " The MVS consists of three subscales: Success (Mat-Success), e.g. I admire people who possess expensive houses, cars and clothes $(\alpha=.76)$, Centrality (Mat-Centrality), e.g., Things that I possess have no particular importance to me (item reversed), $(\alpha=.64)$, and Happiness (Mat-Happiness), e.g., I would be happier if I could afford to buy more things $(\alpha=.76)$. The scale is char- acterised by a satisfactory level of reliability $(\alpha=.85)$. We computed four indices: based on 15 items (Materialism-Total), based on the Success subscale (Mat-Success), based on the Centrality subscale (Mat-Centrality), and based on the Happiness subscale (Mat-Happiness).

\section{Results}

We conducted statistical analyses using the SPSS 26 software. We assessed variables distribution normality with the KolmogorovSmirnov test, homogeneity of variance with the Levine's test, and we used the Student's ttest for independent samples to determine differences between variables. Also, we employed Cohen's d index to calculate the size of the effect. To determine relationships between variables, we used the r-Pearson's correlation analysis along with regression analysis.

Table 1. Descriptive statistics and Pearson's correlation coefficients $(\mathrm{N}=476)$

\begin{tabular}{|c|c|c|c|c|c|c|c|c|c|c|c|c|c|c|c|c|c|c|}
\hline & $\mathrm{M}(\mathrm{SD})$ & 1 & 2 & 3 & 4 & 5 & 6 & 7 & 8 & 9 & 10 & 11 & 12 & 13 & 14 & 15 & 16 & 17 \\
\hline 1. & $55,30(7,98)$ & 1 & & & & & & & & & & & & & & & & \\
\hline 2. & $21,27(4,58)$ & $91^{* *}$ & 1 & & & & & & & & & & & & & & & \\
\hline 3. & $25,05(3,25)$ & $.79^{* * *}$ & $.56^{* *}$ & 1 & & & & & & & & & & & & & & \\
\hline 4. & $46,47(9,89)$ &,$- 16^{* *}$ &,$- 18^{* *}$ &,$- 12^{* *}$ & 1 & & & & & & & & & & & & & \\
\hline 5. & $13,62(4,24)$ & $-26^{* *}$ &,$- 27^{* *}$ &,$- 18^{* *}$ & $.84^{* *}$ & 1 & & & & & & & & & & & & \\
\hline 6. & $16,08(3,44)$ & -06 &,- 08 &,- 03 & $.81^{* *}$ & $.57^{* *}$ & 1 & & & & & & & & & & & \\
\hline 7. & $16,78(4,31)$ & -077 & -089 & -079 & $.82^{* *}$ &, $50^{* *}$ &, $49^{* * *}$ & 1 & & & & & & & & & & \\
\hline 8. & $14,48(3,92)$ & -06 & -,04 & -05 & .08 &, $16^{* *}$ & .04 & .00 & 1 & & & & & & & & & \\
\hline 9. & $11,30(3,77)$ & $-.24^{* *}$ &,$- 19^{* *}$ & $-20^{* * *}$ &,$- 13^{* *}$ & .012 & $-18^{* *}$ & $-18^{* * *}$ & $.50^{* *}$ & 1 & & & & & & & & \\
\hline 10. & $17,52(3,42)$ & $.19^{* * *}$ & $20^{* *}$ & $.21^{* *}$ & $-14^{* *}$ & $-12^{*}$ & $-0,08$ &,$- 14^{* *}$ & $24^{* *}$ & $.17^{* *}$ & 1 & & & & & & & \\
\hline 11. & $27,34(5,24)$ & $.56^{* *}$ & $.55^{* *}$ & $.47^{* *}$ &,$- 18^{* *}$ &,$- 23^{* *}$ &,- 07 &,$- 13^{* *}$ & $.21^{* *}$ & .02 &, $54^{* *}$ & 1 & & & & & & \\
\hline 12. & $18,72(3,34)$ & $23^{* *}$ &, $18^{* *}$ &, $29^{* *}$ & $-0,06$ & -04 & -01 & $-09^{*}$ &,- 023 & $-09^{*}$ & $.37^{* *}$ & $.43^{* *}$ & 1 & & & & & \\
\hline 13. & $11,61(3,24)$ & .08 & 09 &, $10^{*}$ & .05 & .08 &, $11^{*}$ & -05 & -0.02 & .02 & $.28^{* *}$ &, $24^{* *}$ & $.46^{* *}$ & 1 & & & & \\
\hline 14. & $12,46(3,32)$ & .03 & .02 & ,07 & $22^{* * *}$ &, $28^{* *}$ &, $32^{* *}$ &, $12^{* *}$ & $\begin{array}{l}-, 06 \\
-5\end{array}$ & $-13^{* *}$ &, $17^{* *}$ & $.18^{* *}$ &, $29^{* *}$ & $51^{* *}$ & 1 & & & \\
\hline 15. & $16,42(3,99)$ & .04 & .02 &, $12^{*}$ & $.27^{* *}$ & $.32^{* *}$ & $26^{* * *}$ &, $10^{*}$ & .09 & -07 &, $23^{* *}$ & $.13^{* *}$ & $.47^{* *}$ &, $36^{* *}$ & $.34^{* *}$ & 1 & & \\
\hline 16. & $9,29(3,25)$ &,$- 14^{* *}$ &,$- 14^{* *}$ & -09 & $46^{* *}$ & $47^{* * *}$ & $37^{* * *}$ & $30^{* * *}$ & $-0,01$ & -.02 & -08 &,$- 12^{*}$ & $20^{* * *}$ & $.24^{* *}$ & $.22^{* *}$ & $.48^{* *}$ & 1 & \\
\hline 17. & $19,67(4,27)$ & .05 & ,03 & $.14^{* *}$ & $.12^{*}$ & $.16^{* * *}$ & $.10^{*}$ & .03 & $.40^{* *}$ &, $20^{* * *}$ &, $24^{* *}$ &, $29^{* *}$ &, $24^{* *}$ &, $13^{* *}$ &, $112^{*}$ & $.38^{* *}$ & $.21^{* *}$ & 1 \\
\hline
\end{tabular}

Note: 1-NEP-Total, 2-NEP-Human Power, 3-NEP-Limits of Nature, 4-Materialism-Total, 5-Mat-Success, 6Mat-Centrality, 7-Mat-Happiness, 8-Conformity, 9-Tradition, 10-Benevolence, 11-Universalism, 12-Selfdirection, 13-Stimulation, 14-Hedonism, 15-Achievement, 16-Power, 17-Security; M-mean, SDstandard deviation; * $\mathrm{p}<0,05 ;{ }^{* *} \mathrm{p}<0,01 ;^{* * *} \mathrm{p}<0,001$.

Descriptive statistics and correlation coefficients between variables are presented in Table 1 . There are positive correlations between pro-environmental attitudes (with respect to all three indices) and the following values: benevolence, universalism and self-direction; and between one facet of the NEP, expressed as Limits of Nature, with achievement and security values. Significant, but negative correlations we found between the NEP (Total, Human Power and Limits of Nature) and tradition and power values. Regarding the relationship between pro-environmental attitudes and materialism, we can see that only Materialism-Total, along with MaterialismSuccess, correlate significantly, but negatively with the NEP (three indices).

The Student's t-test for independent variables shows that there are statistically significant differences between genders as regards pro-environmental attitudes, when taking into account all three indices. Results reveal 
that women manifested a higher level of a general pro-environmental attitude than men (NEP-Total: $\mathrm{t}=-11,01, p<.001$, Cohen's $d=$ -1,07; women: $M=59,86$; $S D=6,32$; men: $M=52,33$; $\mathrm{SD}=7,39$ ); also, a more pro-environmental attitude manifested by higher scores in the Human Power (reversed) subscale $(t=$ $-11,01, p<.001$, Cohen's $d=-1,08$; women: $M=23,96 ; S D=3,73$; men: $M=19,58 ; S D=4,24)$. The same trend was observed in the Limits of Nature subscale $(t=-7,33, p<.05$, Cohen's $d=$ -0,68; women: $M=26,31 ; S D=2,74$; men: $M=24,22 ; S D=3,26$ ).

We conducted linear regression analysis to identify significant predictors of pro-environmental attitudes (dependent variable) and tested two models. In the first model the set of three facets of materialism was introduced as predictors (Table 2), while in the second model, ten values (Table 3 ).

The first model with three forms of materialism as predictors proved to be well adjusted to the data, $F_{(3,472)}=13,19 \quad(p<0,001)$, and explained $7 \%$ of variance variability in pro-environmental attitudes, measured by the NEP-Total. However, only two explaining variables were significant predictors of the NEP-Total: Mat-Success $\beta=-.34 \quad(t=-6.03$, $p<.001)$ and Mat-Centrality $\beta=.12 \quad(t=2.18$, $p<.001)$. As we can see, the Mat-Success made a higher contribution to the NEP-total variance than the Mat-Centrality.
Table 2. Materialism as predictors of proenvironmental attitudes (NEP-Total) $(\mathrm{N}=476)$

\begin{tabular}{|l|c|c|c|c|c|}
\hline Indicators & $\mathbf{B}$ & SE & $\boldsymbol{\beta}$ & $\mathbf{t}$ & $\mathbf{p}$ \\
\hline $\begin{array}{l}\text { Mat- } \\
\text { Success }\end{array}$ & $\begin{array}{c}- \\
, 640\end{array}$ &, 106 &,- 340 & $-6,028$ &, 000 \\
\hline $\begin{array}{l}\text { Mat- } \\
\text { Centrality }\end{array}$ &, 285 &, 131 &, 123 & 2,182 &, 030 \\
\hline $\begin{array}{l}\text { Mat- } \\
\text { Happiness }\end{array}$ &, 059 &, 099 &, 032 &, 594 &, 553 \\
\hline \multicolumn{7}{|l|}{$R^{2}=0,08 ;$ Adj $R^{2}=0,07 ; F(3 ; 472)=13,19$} \\
\hline
\end{tabular}

Note: $\mathrm{B}=$ non-standardised regression coefficient, $\mathrm{SE}=$ standard error, $\beta=$ standardised regression coefficient, $\mathrm{t}=$ Student's t-test, $\mathrm{p}=$ significance level.

Also, the second model performed for three NEP indices proved to be well adjusted to the data, and explained $39 \%$ of variation in the NEP-Total, 36\% in the NEP-Human Power and $27 \%$ in the NEP-Limits of Nature. We found universalism to be the most significant predictor for all three indices: the NEP-Total $\beta=.64(t=13.62, p<.001)$, the NEP-Power $\beta=.65$ $(\mathrm{t}=13.65, \mathrm{p}<.001)$, and the NEP-Limits of Nature $\beta=.45(t=8.86, p<.001)$. Tradition, which was found to be negatively associated with a pro-environmental attitude, also proved to be a significant predictor in all three cases: $\beta=$ $-.21(t=-4.97, p<.001 ; \beta=-.17(\mathrm{t}=-3.96, \mathrm{p}<.001)$; $\beta=-.17(\mathrm{t}=-3.50, \mathrm{p}<.01)$, respectively. The third value (hedonism) was found to act as a significant negative predictor of the NEP-total $\beta=$ -.10 $(t=-2.32, p<.05)$ and the NEP-Human Power $\beta=-.12(\mathrm{t}=-2.80, \mathrm{p}<.01)$.

Table 3. Results of regression analysis: Values as predictors of pro-environmental attitudes $(\mathrm{N}=476)$

\begin{tabular}{|c|c|c|c|c|c|c|c|c|c|c|c|c|}
\hline \multirow[t]{2}{*}{ Indicators } & \multicolumn{4}{|c|}{ NEP-Total } & \multicolumn{4}{|c|}{ NEP-Human Power } & \multicolumn{4}{|c|}{ NEP-Limits of Nature } \\
\hline & $\boldsymbol{B}$ & $S E$ & $\beta$ & $t$ & $\boldsymbol{B}$ & $S E$ & $\beta$ & $t$ & $B$ & $S E$ & $\beta$ & $t$ \\
\hline Conformity &,- 12 & ,09 &,- 06 & $-1,27$ &,- 06 & 05 &,- 56 & $-1,21$ &,- 07 &, 04 &,- 09 & $-1,72$ \\
\hline Tradition &,- 45 & ,09 &,- 21 & $-4,97^{* * *}$ &,- 21 & ,05 &,- 17 & $-3,96^{* * *}$ & 0,14 & ,04 &,- 17 & $-3,50 * *$ \\
\hline Benevolence &,- 21 & ,11 &,- 09 & $-1,95^{t}$ &,- 10 &, 06 &,- 07 & $-1,56$ &,- 04 & 05 &,- 05 &,- 92 \\
\hline Universalism & 971 &, 07 & 64 & $13,62^{* * *}$ & ,57 &, 04 & 65 & $13,65^{* * *}$ & 28 & 03 & 45 & $8,86^{* * *}$ \\
\hline $\begin{array}{l}\text { Self- } \\
\text { Direction }\end{array}$ &,- 02 & 11 &,- 01 &,- 15 &,- 11 & 07 &,- 08 & $-1,64$ & 09 & 05 & ,09 & 1,71 \\
\hline Stimulation & ,03 & ,114 & ,01 &, 26 & ,08 & ,07 & ,06 & 1,23 &,- 02 &, 05 &,- 02 &,- 31 \\
\hline Hedonism &,- 24 &, 10 &,- 10 & $-2,31^{*}$ &,- 17 &, 06 &,- 12 & $-2,80^{* *}$ &,- 06 &, 05 &,- 06 & $-1,29$ \\
\hline Achievement &, 09 & ,10 &, 04 &, 89 &, 06 &, 06 &, 05 & 1,11 &, 05 &, 04 &, 06 & 1,20 \\
\hline Power &,- 17 & 11 &,- 07 & $-1,57$ &,- 08 & 06 &,- 06 & $-1,26$ &,- 09 &, 05 &,- 09 & $-1,82$ \\
\hline Security &,- 08 &, 08 &,- 04 &,- 930 &,- 07 &, 05 &,- 06 & $-1,43$ &, 05 &, 04 &, 07 & 1,48 \\
\hline & \multicolumn{4}{|c|}{$\begin{array}{l}R^{2}=0,40 ; \text { Adj } R^{2}=0,39 \\
F(1 ; 4650)=31,04\end{array}$} & \multicolumn{4}{|c|}{$\begin{array}{l}R^{2}=0,38 ; \text { Adj } R^{2}=0,36 ; \\
F(10 ; 465)=28,17\end{array}$} & \multicolumn{4}{|c|}{$\begin{array}{l}R^{2}=0,29 ; \operatorname{Adj} R^{2}=0,27 ; \\
F(10 ; 465) 18,50\end{array}$} \\
\hline
\end{tabular}

Note: $\mathrm{B}=$ non-standardised regression coefficient, $\mathrm{SE}=$ standard error, $\beta=$ standardised regression coefficient, $\mathrm{t}=$ Student's t-test, $\mathrm{p}=$ significance level; ${ }^{* * *} \mathrm{p}<.001 ;{ }^{* *} \mathrm{p}<.01{ }^{*} \mathrm{p}<.05 ;{ }^{\mathrm{t}} \mathrm{p}<.10$ 


\section{Discussion and conclusions}

The results have shown that women, as compared to men, manifest a higher level of pro-environmental attitudes. This is consistent with previous reports and can be explained by assigned social roles. Men are usually socialized to be breadwinners, to deal with finances and ensure material security for their family. Women, on the other hand, are most often socialised to be compassionate, nurturing, cooperative, to care for others, which may be reflected in pro-environmental activities in daily routines (such as sorting waste or using energy-saving facilities).

Both predictive models, the one based on values, and the one based on materialism, have proven to predict pro-environmental attitudes. In the case of centrality of materialism, one of the possible explanations is materialistic individuals' interest in goods and services employing new technologies aimed at protecting the environment. As an example, investing money in renewable energy sources for one's home or buying electric cars. Success, on the other hand, turned out to be negatively correlated with pro-environmental attitudes. A possible explanation of this is the fact that the stronger is one's pursuit of success, the stronger is their focus on possession of goods and services, and the weaker on caring for the environment (Andersson, Nässén, 2016). Results of the study confirm the previous reports, which link materialism and pro- environmental attitudes (Gatersleben, Jackson, Meadows et al. 2018; (Gu, Gao, Wang et al., 2020).

The model based on values explained up to $40 \%$ of the variance of variables. The value which, in accordance with the theoretical assumptions, has proven to be positively correlated with the pro-environmental attitude, is universalism, which implies respect and caring for nature and the environment. In turn, values that have proven to be negatively correlated with the attitude are hedonism and tradition. Preference for tradition may relate to a higher conservatism, i.e., reluctance to change, which in turn may be linked to difficulties in acquiring new pro-environmental habits. The same goes for the lifestyle focused around the pursuit of pleasure (Cieciuch, Schwartz 2018).

However, this study has some limitations. The participants of the study were only young people under 30 years of age. In addition, the study was cross-sectional, so it is not easy to make judgments about causes and effects. Despite these limitations, the study brings new data on the relationship between pro-environmental attitudes, materialism, and values in a Polish sample. In future research, a longitudinal study on the variables analysed seems to be of interest. The data may have practical value and can be used for the formation and promotion of ecological behaviour.

\section{References}

Andersson, D., Nässén, J. (2016) Should environmentalists be concerned about materialism? An analysis of attitudes, behaviours and greenhouse gas emissions. Journal of Environmental Psychology, no. 48, pp. 1-11. DOI: 10.1016/j.jenvp.2016.08.002 (In English)

Belk, R. W. (1985) Materialism: Trait Aspects of Living in the Material World. Journal of Consumer Research, no. 12 (3), pp. 265-280. DOI: 10.1086/208515 (In English)

Byrka, K. (2015) Łańcuchowe zmiany zachowań w kontekście ochrony środowiska i promocji zdrowai. Warszawa: Wydawnictwo Naukowe PWN. (In Polish)

Cieciuch, J., Schwartz, S. H. (2012) The Number of Distinct Basic Values and Their Structure Assessed by PVQ-40. Journal of Personality Assessment, vol. 94 (3), pp. 321-328. DOI: 10.1080/00223891.2012.655817 (In English)

Cieciuch, J., Schwartz, S. H. (2018) Pomiar wartości w kołowym modelu Schwartza. In: H. Gasiul (ed.), Metody badania emocji i motywacji, Warszawa: Difin, pp. 307-334. (In English)

Cieciuch, J., Zaleski, Z. (2011) Polska adaptacja Portretowego Kwestionariusza Wartości Shaloma Schwartza. Czasopismo Psychologiczne, no. 17 (2), pp. 251-262. (In Polish)

Cohen, J. (1992) A power primer. Psychological Bulletin, no. 112, pp. 155-159. (In English) 
Cordano, M., Welcomer, S. A., Scherer, R. F. (2003) An Analysis of the Predictive Validity of the New Ecological Paradigm Scale. The Journal of Environmental Education, no. 34 (3), pp. 22-28. DOI: 10.1080/00958960309603490 (In English)

Dittmar, H., Bond, R., Hurst, M., Kasser, T. (2014) The relationship between materialism and personal well-being: A meta-analysis. Journal of Personality and Social Psychology, no. 107 (5), pp. 879-924. DOI: $10.1037 / a 0037409$ (In English)

Dunlap, R. E., Van Liere, K. D., Mertig, A. G. et al. (2000) New Trends in Measuring Environmental Attitudes: Measuring Endorsement of the New Ecological Paradigm: A Revised NEP Scale. Journal of Social Issues, no. 56 (3), pp. 425-442. DOI: 10.1111/0022-4537.00176 (In English)

Dyr, W., Prusik, M. (2020) Measurement of proecological attitudes within new ecological paradigm in Polish current settings. Social Psychological Bulletin, no. 15 (3). [Online]. Available at: https://doi.org/10.32872/spb.3697 (accessed 07.08.2021). (In English)

Erdogan, N. (2009) Testing the New Ecological Paradigm Scale: Turkish case. African Journal of Agricultural Research, no. 40(10), 1023-1031. (In English)

Gatersleben, B., Jackson, T., Meadows, J. et al. (2018) Leisure, materialism, well-being and the environment. European Review of Applied Psychology, no. 68 (3), pp. 131-139. DOI: 10.1016/j.erap.2018.06.002_(In English)

Górnik-Durose, M. (2016) Polska adaptacja skali wartości materialnych (MVS) - właściwości psychometryczne wersji pełnej i wersji skróconych. Psychologia Ekonomiczna, no. 9, pp. 5-21. DOI: 10.15678/PJOEP.2016.09.01

Gu, D., Gao, S., Wang, R. et al. (2020) The Negative Associations Between Materialism and Pro-Environmental Attitudes and Behaviors: Individual and Regional Evidence From China. Environment and Behavior, no. 52 (6), pp. 611-638. DOI: 10.1177/0013916518811902 (In English)

Hunter, L. M., Hatch, A., Johnson, A. (2004) Cross-national gender variation in environmental behaviors. Social science quarterly, no. 85(3), pp. 677-694. (In English)

Hurst, M., Dittmar, H., Bond, R., Kasser, T. (2013) The relationship between materialistic values and environmental attitudes and behaviors: A meta-analysis. Journal of Environmental Psychology, no. 36, pp. 257-269. DOI: 10.1016/j.jenvp.2013.09.003 (In English)

Karp, D. G. (1996) Values and their Effect on Pro-Environmental Behavior. Environment and Behavior, no. 28 (1), pp. 111-133. DOI: 10.1177/0013916596281006 (In English)

Kasser, T., Ryan, R. M. (1993) A dark side of the American dream: Correlates of financial success as a central life aspiration. Journal of Personality and Social Psychology, no. 65 (2), pp. 410-422. DOI: 10.1037/0022-3514.65.2.410 (In English)

Kilbourne, W., Pickett, G. (2008) How materialism affects environmental beliefs, concern, and environmentally responsible behavior. Journal of Business Research, no. 61(9), pp. 885-893. DOI: 10.1016/j.jbusres.2007.09.016 (In English)

Liobikienè, G., Liobikas, J., Brizga, J. et. al. (2020) Materialistic values impact on pro-environmental behavior: The case of transition country as Lithuania. Journal of Cleaner Production, no. 244. [Online]. Available at: https://doi.org/10.1016/j.jclepro.2019.118859 (accessed 07.08.2021). (In English)

Liu, X., Vedlitz, A., Shi, L. (2014) Examining the determinants of public environmental concern: Evidence from national public surveys. Environmental Science \& Policy, no. 39, pp. 77-94. DOI: 10.1016/j.envsci.2014.02.006 (In English)

Lundmark, C. (2007) The new ecological paradigm revisited: Anchoring the NEP scale in environmental ethics. Environmental Education Research, no. 13(3), pp. 329-347. DOI: 10.1080/13504620701430448 (In English)

Plombon, E. (2011) Factors Affecting Pro-Environmental Attitudes. UW-L Journal of Undergraduate Research, vol. 14, pp. 1-14. (In English)

Richins, M. L., Dawson, S. (1992). A Consumer Values Orientation for Materialism and Its Measurement: Scale Development and Validation. Journal of Consumer Research, no. 19 (3), pp. 303-316. DOI: 10.1086/209304 (In English)

Schwartz, S. H., Melech, G., Lehmann, A. et al. (2001) Extending the Cross-Cultural Validity of the Theory of Basic Human Values with a Different Method of Measurement. Journal of Cross-Cultural Psychology, no. 32 (5), pp. 519-542. DOI: 10.1177/0022022101032005001 (In English) 
Sevgili, F., Cesur, S. (2014) The Mediating Role of Materialism on the Relationship between Values and Consumption. Educational Sciences: Theory and Practice, no. 14 (6), pp. 2083-2096. DOI: 10.12738/estp.2014.6.2164 (In English)

Shrum, L. J., Wong, N., Arif, F., Chugani, S. K., Gunz, A., Lowrey, T. M., Nairn, A., Pandelaere, M., Ross, S. M., Ruvio, A., Scott, K., Sundie, J. (2013) Reconceptualizing materialism as identity goal pursuits: Functions, processes, and consequences. Journal of Business Research, no. 66 (8), pp. 1179-1185. DOI: 10.1016/j.jbusres.2012.08.010 (In English)

Zelezny, L. C., Chua, P. P., Aldrich, C. (2000) Elaborating on gender differences in environmentalism. Journal of Social issues, no. 56 (3), pp. 443-458. (In Polish) 